\title{
RNA Metabolism in Myotonic Dystrophy \\ Patient Muscle Shows Decreased Insulin Receptor RNA and Protein Consistent with Abnormal Insulin Resistance
}

\author{
Amelia Morrone, ${ }^{\star \S}$ Elena Pegoraro, ${ }^{\star \ddagger}$ Corrado Angelini, ${ }^{\star \ddagger}$ Enrico Zammarchi, ${ }^{\S}$ Giampiero Marconi, ${ }^{\text {and Eric P. Hoffman }}{ }^{\star}$ \\ * Department of Molecular Genetics and Biochemistry, Department of Human Genetics, and Department of Pediatrics, University of \\ Pittsburgh School of Medicine, Pittsburgh, Pennsylvania 15261; ${ }^{\ddagger}$ Department of Neurology, University of Padova, Padova, Italy; and \\ ${ }^{\S}$ Department of Pediatrics and ${ }^{\|}$Department of Neurology, University of Florence, Florence, Italy
}

\begin{abstract}
Myotonic dystrophy is a dominantly inherited clinically variable multisystemic disorder, and has been found to be caused by heterozygosity for a trinucleotide repeat expansion mutation in the $3^{\prime}$ untranslated region of a protein kinase gene (DM kinase). The mechanisms by which the expanded repeat in DNA results in a dominant biochemical defect and the varied clinical phenotype, is not known. We have recently proposed a model where disease pathogenesis may occur at the RNA level in myotonic dystrophy: the mutant DM kinase RNA with the expansion mutation may disrupt cellular RNA metabolism in some general manner, as evidenced by defects in RNA processing of the normal DM kinase gene in heterozygous patients (dominant negative RNA mutation). Here we further test this hypothesis by measuring RNA metabolism of other genes in patient muscle biopsies (nine adult onset myotonic dystrophy patients, two congenital muscular dystrophy patients, four normal controls, and four myopathic controls). We focused on the insulin receptor gene because of the documented insulin resistance of DM patients. We show that there is a significant decrease in insulin receptor RNA in both total RNA and RNA polyA+ pools relative to normal and myopathic control muscles $(P<0.002)$, measured relative to both dystrophin RNA and muscle sodium channel RNA. We also show reductions in insulin receptor protein. Our results reinforce the concept of a generalized RNA metabolism defect in myotonic dystrophy, and offer a possible molecular mechanism for the increased insulin resistance observed in many myotonic dystrophy patients. (J. Clin. Invest. 1997. 99:1691-1698.) Key words: myotonic dystrophy $\bullet$ insulin resistance $\bullet$ trinucleotide repeat expansion disorder $\bullet$ insulin receptor $\bullet$ DM-kinase
\end{abstract}

Address correspondence to Eric P. Hoffman, Ph.D., Department of Molecular Genetics and Biochemistry, W1211 BSTWR, University of Pittsburgh School of Medicine, Pittsburgh, PA 15261. FAX: 412-6241401; E-mail: eric@hoffman.mgen.pitt.edu

Received for publication 8 November 1996 and accepted in revised form 24 January 1997.

J. Clin. Invest.

(C) The American Society for Clinical Investigation, Inc. 0021-9738/97/04/1691/08 \$2.00

Volume 99, Number 7, April 1997, 1691-1698

\section{Introduction}

Myotonic dystrophy (DM) $)^{1}$ is an autosomal dominant neuromuscular disease with an estimated incidence in adults of about 1 in 8,500 individuals (1). Presenting clinical symptoms range from very mild (cataracts in middle age), to very severe (neonatal lethal hypotonia). The classical presentation includes myotonia and progressive weakness and wasting of distal skeletal muscles. Many organ systems are involved, however, with patients often showing cardiac conduction defects, smooth muscle involvement, hypersomnia, endocrine problems (increased insulin resistance), and premature balding and testicular atrophy in males (2). The disease is caused by an unstable CTG trinucleotide repeat in the $3^{\prime}$ untranslated region of the DM kinase gene on chromosome 19 q $13.3(3,4,5,6,7)$.

The effect of the expanded trinucleotide repeat on gene and protein expression is actively being investigated for myotonic dystrophy, and many of the other trinucleotide repeat disorders (Fragile X, bulbospinal muscular atrophy, Huntington's disease, spinocerebellar ataxias, Friedreich's ataxia, etc.). In recessively inherited Fragile X and Freidreich's ataxia, gene expression data is consistent with loss of function of the protein product of the corresponding gene, as expected in all recessively inherited disorders. In Fragile X, the trinucleotide repeat is at the $5^{\prime}$ end of the gene, where it appears to decrease transcription via hypermethylation of the promoter (8). In Freidreich's ataxia, the trinucleotide repeat is in an intron, where it interferes with correct formation of RNA (9). All of the other trinucleotide repeat disorders except Myotonic dystrophy show the expanded repeat in the coding sequence of the gene, leading to extensions of a polyglutamine tract in the protein product. This alteration of the protein product likely leads to a gain or a change of function, consistent with the dominant inheritance pattern of all of these disorders (10). The expansion in the DM kinase gene causing myotonic dystrophy is unique in its location in the $3^{\prime}$ untranslated region of the gene. The location of the repeat is difficult to reconcile with the dominant inheritance pattern of myotonic dystrophy. Most dominantly inherited disorders show expression of abnormal protein products (change of function or dominant negative). The DM kinase protein encoded by the abnormal gene, however, should show no sequence variations, and hence should not show a change of function or dominant negative effect at the protein level.

Early studies of transcription patterns of the normal and mutant DM kinase gene in affected heterozygous patients were contradictory, some showing increased (11), (but most

1. Abbreviations used in this paper: DM, myotonic dystrophy; Dys, dystrophin; InR, insulin receptor. 
showing decreased) expression from the mutant gene $(12,13$, $14,15)$. Using patient muscle biopsies, we recently showed that the DM kinase gene containing the expansion mutation is indeed transcribed at levels similar to the normal gene. Both the normal and the abnormal RNAs accumulate in total RNA pools, however, the normal and mutant RNAs showed defects in RNA processing (16). Based on these results, we hypothesized that myotonic dystrophy may represent the first dominant RNA disease, where generalized disruptions of RNA metabolism mediated by accumulation of the abnormal RNA could cause the varied clinical symptoms. This model could offer an explanation for the dominant inheritance pattern and dramatic clinical variability of myotonic dystrophy: different subpopulations of RNAs could be altered in a cell type and in a developmentally specific pattern. If this hypothesis is true, then it should be possible to identify abnormal process and/or accumulation of RNAs from other specific genes in patient muscle. The most likely candidates for abnormalities would be those genes whose gene products may be involved in the disease pathogenesis. It is well documented that myotonic dystrophy patients show increased insulin resistance $(17,18,19,20$, 21). Some endocrinological studies of myotonic dystrophy patients have suggested that the insulin resistance could be a consequence of decreased receptor number (22). We hypothesized that the insulin resistance could be the result of abnormal metabolism of insulin receptor RNA in patient cells (dominant-negative RNA). To test this hypothesis, we studied expression of the insulin receptor gene in myotonic dystrophy patient muscle biopsies.

\section{Methods}

Muscle biopsies. We used preexisting muscle biopsies collected for diagnostic purposes from 17 patients. The muscles had been flash frozen after biopsy in isopentane cooled in liquid nitrogen, and were stored in airtight containers at $-80^{\circ} \mathrm{C}$ until analysis. Nine biopsies were from patients with classical adult onset myotonic dystrophy, and two were from congenital muscular dystrophy patients. The presence of a CTG trinucleotide repeat expansion ranging from 83-2300 repeats was determined by DNA studies of muscle and/or blood. Four biopsies (myopathic controls) were from patients referred for dystrophin protein testing. All had myopathic histopathology and clinical symptoms, but dystrophin was normal in size and amount. Four biopsies that showed normal dystrophin protein and no evidence of histopathology by hematoxylin and eosin staining of cryosections were chosen as normal controls.

Characterization of repeat expansions. Molecular analyses of repeat expansion sizes were performed using Southern blotting as previously described (23). Analyses were done by Massimo Gennarelli, Department of Public Health and Cell Biology, Tor Vergata University of Rome, Italy.

Total RNA isolation, polyA+ purification and cDNA synthesis. 10-100 mg of each muscle biopsy was homogenized with a polytron homogenizer (Brinkmann Instruments, Inc., Westbury, NY) in guanidium isothiocyanate buffer, and the RNA was pelleted through a $\mathrm{CsCl}$ cushion. Samples were rinsed with cold $70 \%$ ethanol, and resuspended in TE and 1\% SDS (15). RNA integrity and concentration were verified by agarose gel electrophoresis. Samples were reprecipitated with ethanol to remove SDS before cDNA synthesis.

PolyA + RNA was purified from $2.5 \mu \mathrm{g}$ of total RNA by Fasttrack mRNA isolation kits (Invitrogen Corp., San Diego, CA). cDNA was made from both total RNA and polyA+ RNA. About $500 \mu \mathrm{g}$ of total RNA, and polyA + RNA isolated from $500 \mu \mathrm{g}$ of total RNA, were dissolved in $25 \mu \mathrm{l}$ DEPC water and reverse transcribed into cDNA using a mixture of six sequence-specific antisense primers directed against six distinct genes, as follows: adult skeletal muscle sodium channel (24): 4836R, 5'CTCGCTGCTCTCCTCTGTGG; insulin receptor (25): 4239R, 5'GCCTCCGTTCATGTGTGTGT; dystrophin (26): 11384R, 5'AAACCATGCGGGAATCAG; creatine kinase (27): 1222R, 5'ACTTCTGGGCGGGATCAT; transferrin (28): 2331R, 5'CAGCTCCCTGAATAGTCCAAGTA; DM kinase (3): 1201R, 5'CATCCTGTGGGGACACCGACC.

Each cDNA synthesis contained $70 \mu \mathrm{g}$ of each sequence-specific primer. After heating to $68^{\circ} \mathrm{C}$ for $2 \mathrm{~min}$ and chilling on ice, the reaction was brought up to the volume of $50 \mu \mathrm{l}$ with buffer containing $25 \mathrm{U}$ of AMV reverse transcriptase, $20 \mathrm{U}$ of placental ribonuclease inhibitor, $10 \mathrm{mM}$ each dNTPs and buffers as per manufacturer's instructions (Boehringer Mannheim Biochemicals, Indianapolis, IN). cDNA synthesis was done at $42^{\circ} \mathrm{C}$ for $1 \mathrm{~h}$.

Multiplex RT-PCR amplification of cDNAs. Primer sets for coamplification of human RNAs corresponding to dystrophin, insulin receptor, $\mathrm{Na}^{+}$channel, creatine kinase, transferrin, and DM kinase were designed to vary a relatively small amount in size. For each set, the forward primer was synthesized with an amino link residue at the $5^{\prime}$ end, and the primer was covalently coupled via an ester linkage to carboxyl-fluorescein (Molecular Probes, Inc., Eugene, OR) as previously described (29). For each PCR product, the reverse primer was designed upstream of the sequence-specific reverse primer used for cDNA synthesis. Primer sequences were as follows: adult skeletal muscle sodium channel $\left(\mathrm{Na}^{+}\right)$: 4702F: 5'-GGT GAC TGC GGC AAC CCC TCC A, 4820R: 5'-GTG GCC ACA TTG AAG TTC TCC; insulin receptor (InR): 4090F: 5'-GAG ATG GAG TTT GAG GAC ATG, 4223R: 5'-GTG TAA GGG ATG TGT TCC TCG TAG; dystrophin (Dys): 5369F: 5'-AGG CAG AAC TGA ATG ACA TAC G, 5533R: 5'-CTT TCC AGT CTT AAT TCT GTG T; DM kinase (DMK): 1014F: 5'-ACT TGT CGG ACA TTC GGG AAG GT, 1155R: 5'-TGG CTC AAG CAG CTG CTC GG; creatine kinase M (CKM): 997F: 5'-AGTTCG AGG AGA TCC TCA CCC GC, 1196R: 5'-ATG GAC TGG CCT TTC TCC AAC TTC; and transferrin receptor (TfR): 2151F: 5'-CTC TCT CCC TAC GTA TCT CC, 2305R: 5'-AGA GCC AAC TGG TTT CTG AAC. Hemi-nested multiplex fluorescent RT-PCR with six different products to check each total RNA and polyA + RNA sample was done (see Fig. 1). A mix of $70 \mathrm{ng}$ of each primer set (above), and $2 \mu \mathrm{l}$ of cDNA corresponding to about $20 \mathrm{ng}$ of total RNA, was amplified with $2.5 \mathrm{U}$ Ampli Taq DNA polymerase (Perkin Elmer Cetus Instruments, Branchburg, NJ), $25 \mathrm{mM}$ of dNTPs, and $1 \times$ PCR reaction buffer in a total volume of $25 \mu \mathrm{l}$. Cycling conditions for these six primers sets were $94^{\circ} \mathrm{C}$ for $1 \mathrm{~min}, 60^{\circ} \mathrm{C}$ for $1 \mathrm{~min}$, and $72^{\circ} \mathrm{C}$ for $1 \mathrm{~min}$.

Quantitation of insulin receptor $R N A$ by multiplex fluorescent $R T$ $P C R$. Multiplex RT-PCR and quantitation of fluorescent PCR products of insulin receptor RNA relative to dystrophin, $\mathrm{Na}^{+}$channel, creatine kinase, or transferrin RNA, was done as previously described (30). Standardized mixes of primers were made, and cDNA corresponding to $\sim 20 \mathrm{ng}$ of total RNA amplified with primer mixes for 22 cycles using standard conditions (denaturation at $94^{\circ} \mathrm{C}$ for $3 \mathrm{~min}, 94^{\circ} \mathrm{C}$ for $1 \mathrm{~min}, 50^{\circ} \mathrm{C}$ for $1 \mathrm{~min}$, and $72^{\circ} \mathrm{C}$ for $1 \mathrm{~min}$ for $10 \mathrm{cycles}$; and then an additional 12 cycles at $94^{\circ} \mathrm{C}$ for $1 \mathrm{~min}, 60^{\circ} \mathrm{C}$ for $1 \mathrm{~min}$, and $72^{\circ} \mathrm{C}$ for 1 min [total 22 cycles]).

Fluorescent RT-PCR products corresponding to $2 \mathrm{ng}$ of total input RNA were denatured and loaded on an ABI 373A DNA automated sequencer $(6 \%$ acrylamide, $8 \mathrm{M}$ urea, $0.5 \times \mathrm{TBE})$, using a ROX/fluorescein matrix standard (both from Applied Biosystems, Inc. Foster City, CA). ROX-labeled markers (Applied Biosystems) were included as internal size standards. Computer lane tracking was done manually based on gel images, and tracked lanes integrated using the GeneScan software (Applied Biosystems). Peak areas corresponding to expected RT-PCR product sizes were determined, and peak area ratios of insulin receptor (relative to internal control dystrophin or sodium channel) were calculated. Peak area ratios were normalized to the average of control biopsy values, and were presented with standard errors. Three to six separate RT-PCR measurements were done per patient biopsy. 
Statistical significance was done using ANOVA analysis of variance using all calculated ratios.

Quantitative immunoblotting. Cryosections of muscle biopsies were solubilized in sample buffer $(10 \%$ SDS, $0.1 \mathrm{M}$ Tris $\mathrm{pH} 8,5 \mathrm{~mm}$ EDTA, and $10 \mathrm{~mm}$ DTT), and proteins were electrophoretically separated on $3.5-12.5 \%$ gradient SDS-PAGE gels and transferred to nitrocellulose as previously described (31). Quadruplicate immunoblots were incubated with the following antibodies: rabbit $\alpha$-human insulin receptor polyclonal (Signal Transduction, Inc., Lexington, KY), and monoclonals-directed fast-twitch myosin heavy chain (F58) (32), and fast-twitch $\mathrm{Ca}^{2+} \mathrm{Mg}^{2+}$ ATPase (D2) (33). Second antibodies were conjugated to horseradish peroxidase, and immuno complexes were visualized using chemiluminescence (ECL; Amersham).

Quantitations were done using Bioscan. Statistical comparisons were done using Student's t-test.

Immunofluorescence. Cryosections $(4 \mu \mathrm{m})$ were thawed on Superfrost slides (Fisher Scientific Co., Pittsburgh, PA) and processed both unfixed, and fixed with cold acetone. Blocking and washes were done in PBS with $10 \%$ horse serum. Antibodies used were for fasttwitch $\mathrm{Ca}^{2+} \mathrm{Mg}^{2+}$ ATPase (D2) (38), and for the $\alpha$ subunit of the in- sulin receptor (34). Visualization was done with species-specific antibodies bound by Cy3 (Jackson Laboratories, Bar Harbor, ME). Photodocumentation was done using a fluorescent microscope (FXA; Nikon Inc., Melville, NY).

\section{Results}

RNA studies. RNA was isolated from 17 muscle biopsies (nine adult onset myotonic dystrophy patients, two congenital myotonic dystrophy patients, four normal controls, and four myopathic disease controls) (Table I). For each RNA sample, 100 ng of total RNA, and polyA+ RNA corresponding to $100 \mathrm{ng}$ of total RNA, were reverse-transcribed into cDNA using six different sequence-specific primers simultaneously (see Methods). Approximately $20 \mathrm{ng}$ of each total and corresponding polyA + cDNA was amplified using internal sequence-specific primers in three separate mixtures. One qualitative multiplex amplification contained six different $\mathrm{PCR}$ products $\left(\mathrm{Na}^{+}\right.$chan-

Table I. Clinical and Molecular Data in Nine DM Patients, Two Congenital DM Patients (cDM), and Four Myopathic Controls (MC)

\begin{tabular}{|c|c|c|c|c|c|c|c|c|}
\hline \multirow{2}{*}{$\begin{array}{l}\text { Patient } \\
\text { No. }\end{array}$} & \multirow{2}{*}{$\begin{array}{l}\text { Age of } \\
\text { biopsy }\end{array}$} & \multirow{2}{*}{$\begin{array}{l}\text { Age of } \\
\text { onset }\end{array}$} & \multicolumn{5}{|c|}{ Clinical severity } & \multirow{2}{*}{$\begin{array}{l}\text { CTG } \\
\text { repeats }\end{array}$} \\
\hline & & & Muscle & Endocrine & Brain & Heart & Eye & \\
\hline DM1 & $41 \mathrm{yr}$. & 23 & Myotonia, distal atrophy & Normal & $\begin{array}{l}\text { School } \\
\quad \text { difficulties }\end{array}$ & Normal & Lens opacity & ND \\
\hline DM2 & $29 \mathrm{yr}$. & 12 & $\begin{array}{l}\text { Myotonic facies, } \\
\text { myotonia, distal atrophy }\end{array}$ & Thyroid goiter & Normal & Mitral prolapse & Lens opacity & 715 \\
\hline DM3 & $22 \mathrm{yr}$. & 15 & Myotonia, distal atrophy & $\begin{array}{l}\text { Marked testicular } \\
\text { atrophy, } \\
\text { hypospermatogenesis }\end{array}$ & Normal & $\begin{array}{l}\text { Slight right } \\
\text { ventricle } \\
\text { dilatation }\end{array}$ & $\begin{array}{l}\text { Bilateral } \\
\text { cataract }\end{array}$ & 638 \\
\hline DM4 & $58 \mathrm{yr}$. & 50 & $\begin{array}{l}\text { Myotonia, slight distal } \\
\text { atrophy }\end{array}$ & Normal & Normal & $\begin{array}{l}\text { Slight mitral and } \\
\text { tricuspide reflux }\end{array}$ & Normal & 205 \\
\hline DM5 & $26 \mathrm{yr}$. & 20 & Distal atrophy & Normal & Normal & Conduction defect & Cataracts & 180 \\
\hline DM6 & $27 \mathrm{yr}$. & 24 & $\begin{array}{l}\text { Myotonia, distal } \\
\text { atrophy, weakness }\end{array}$ & Normal & $\begin{array}{l}\text { Q.I. }=73 \\
\quad(\text { WAIS test })\end{array}$ & Normal & Lens opacity & 1550 \\
\hline DM7 & $46 \mathrm{yr}$. & 42 & Myotonia & $\begin{array}{l}\text { Marked } \\
\text { hypospermatogenesis }\end{array}$ & Normal & $\begin{array}{l}\text { Abnormal } \\
\text { ventricular } \\
\text { potentials }\end{array}$ & Normal & 83 \\
\hline DM8 & $15 \mathrm{yr}$. & 11 & $\begin{array}{l}\text { Myotonic facies, } \\
\text { myotonia, mild distal } \\
\text { atrophy }\end{array}$ & Normal & Normal & $\begin{array}{l}\text { Mild right } \\
\text { ventricle } \\
\text { dilatation }\end{array}$ & Normal & 564 \\
\hline DM9 & $42 \mathrm{yr}$. & 38 & $\begin{array}{l}\text { Myotonia, distal } \\
\text { atrophy, weakness }\end{array}$ & Hypospermatogenesis & $\begin{array}{l}\text { Q.I. }=108 \\
\quad(\text { WAIS test })\end{array}$ & $\mathrm{I}^{\circ}$ Heart block & $\begin{array}{l}\text { Bilateral } \\
\text { cataract }\end{array}$ & 265 \\
\hline cDM1 & $2 \mathrm{yr}$. & - & $\begin{array}{l}\text { Talipes, severe } \\
\text { hypotonia, weakness, } \\
\text { atrophy }\end{array}$ & Normal & $\begin{array}{l}\text { Severe mental } \\
\text { retardation }\end{array}$ & Normal & Normal & 2300 \\
\hline cDM2 & $10 \mathrm{mo}$. & - & $\begin{array}{l}\text { Talipes, severe } \\
\text { hypotonia, weakness, } \\
\text { atrophy }\end{array}$ & Normal & $\begin{array}{l}\text { Severe mental } \\
\text { retardation }\end{array}$ & Normal & Normal & 1328 \\
\hline $\mathrm{MC1}$ & $10 \mathrm{yr}$. & - & Mild weakness & Normal & Normal & Normal & Normal & ND \\
\hline $\mathrm{MC} 2$ & $16 \mathrm{yr}$. & - & Proximal weakness & Normal & $\begin{array}{l}\text { Slight mental } \\
\text { retardation }\end{array}$ & Normal & Normal & ND \\
\hline MC3 & $22 \mathrm{yr}$. & - & Progressive myopathy & Normal & Normal & Normal & Normal & ND \\
\hline $\mathrm{MC4}$ & $10 \mathrm{yr}$. & 6 & Proximal weakness & Normal & Normal & Normal & Normal & ND \\
\hline
\end{tabular}

$\mathrm{ND}=$ not determined 


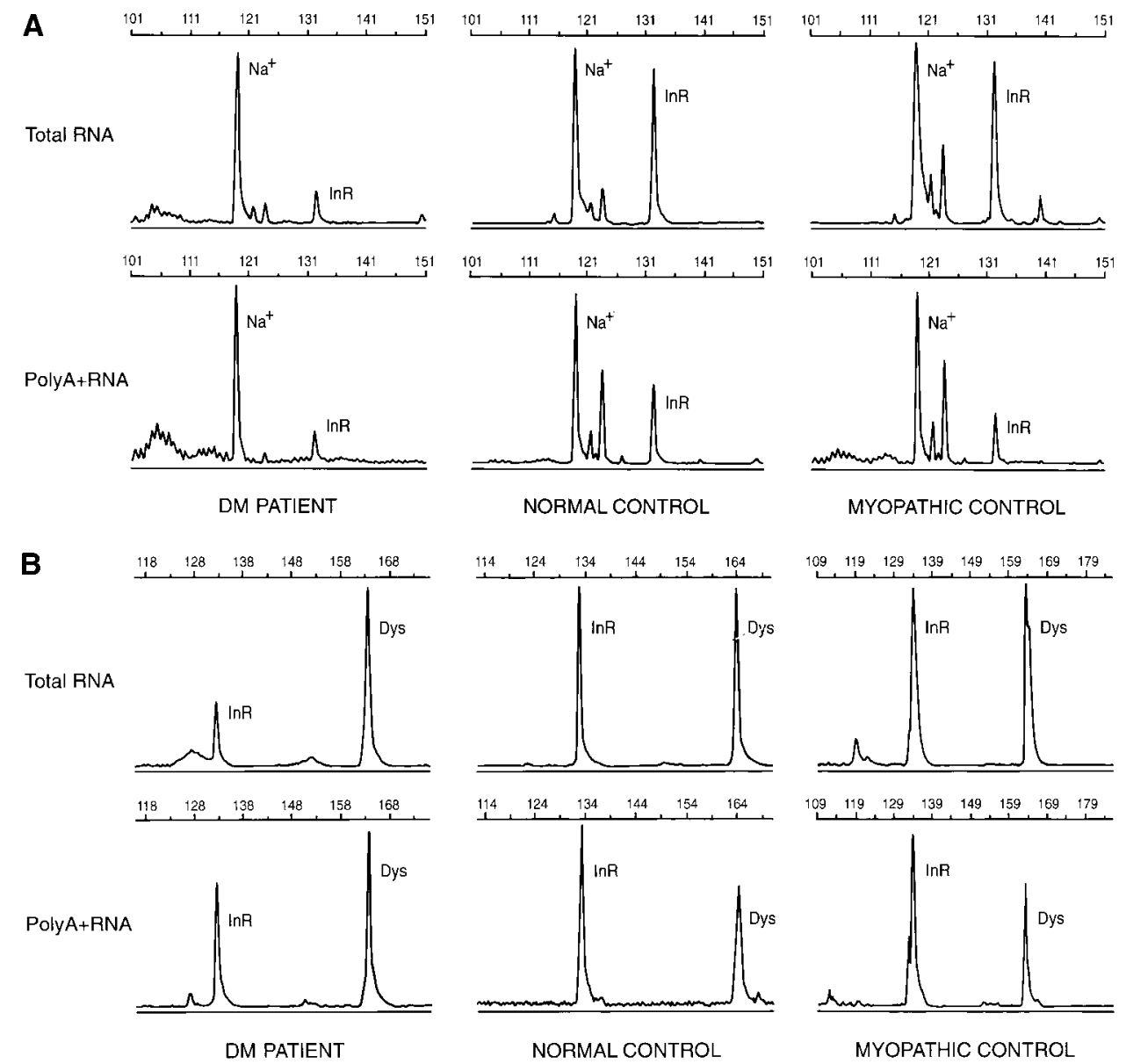

Figure 1. Steady state levels of the insulin receptor RNA are reduced in both total and polyA+ RNA pools. Shown are examples of automated sequencer traces of QMF RT-PCR of the insulin receptor (InR) versus dystrophin (Dys) $(A)$, and the insulin receptor versus sodium channel $\left(\mathrm{Na}^{+}\right)(B)$. Traces are shown for both total RNA, and polyA+ RNA, from adult onset myotonic dystrophy patient muscle biopsies (DM Patient), normal muscle (normal control), and biopsies from patients with muscle disease unrelated to myotonic dystrophy (myopathic control). RNA isolated from muscle biopsies of myotonic dystrophy patients consistently showed lower levels of InR RNA relative to both dystrophin RNA and sodium channel RNA compared to either normal control muscle or myopathic control muscle. The lower levels were apparent in both total RNA and polyA + RNA pools. nel 118 bp, InR 133 bp, DMK 140 bp, TfR 155 bp, CKM 199 bp). This assay was used to check the integrity of the RNAs (data not shown).

Two quantitative mixes were used. One contained both insulin receptor (InR) and dystrophin (Dys) (exon 37) primers. The second quantitative amplification contained both insulin receptor (InR) and sodium channel $\left(\mathrm{Na}^{+}\right)$primers. RT-PCR products ( 22 cycles) corresponding to $2 \mathrm{ng}$ of input total RNA were electrophoresed on an ABI automatic sequencer (373A) to quantitate amplification products using peak area. From two different cDNA syntheses, 3-6 different RT-PCR amplifications of InR and Dys were quantitated for each data point (Fig. 1) (Table II). A similar assay was done for insulin receptor (InR) and sodium channel $\left(\mathrm{Na}^{+}\right)$(Fig. 1) (Table II).

Adult onset myotonic dystrophy and congenital myotonic dystrophy patient muscle biopsies showed a statistically significant decrease in insulin receptor RNA in the total RNA pools relative to dystrophin (exon 37) (Fig. $2 A$ ). Both adult and congenital DM patients showed $50 \%$ of insulin receptor RNA levels seen in controls $(P=0.0000014)$. In polyA + pools, the average insulin receptor RNA levels in DM patients also showed a decrease in InR polyA + RNA, to levels $\sim 65 \%$ of normal $(P=0.018)$ (Fig. $2 A)$.

The observed statistically significant decrease in insulin receptor in both total RNA and in polyA+ RNA pools presumed that dystrophin RNA levels were invariant between the different groups of patients. To rule out alterations of dystro-
Table II. Quantitative Studies of Insulin Receptor Expression in Total RNA and PolyA+RNA in DM Patients and Myopathic Controls

\begin{tabular}{lcccc}
\hline $\begin{array}{c}\text { Patient } \\
\text { No. }\end{array}$ & $\begin{array}{c}\text { Average } \\
\text { total RNA } \\
\text { InR/Dys } \\
\text { ratio }\end{array}$ & $\begin{array}{c}\text { Average } \\
\text { PolyA+ } \\
\text { InR/Dys } \\
\text { ratio }\end{array}$ & $\begin{array}{c}\text { Average } \\
\text { total RNA } \\
\text { of InR/Na+ } \\
\text { ratio }\end{array}$ & $\begin{array}{c}\text { Average } \\
\text { PolyA+ } \\
\text { of InR/Na+ } \\
\text { ratio }\end{array}$ \\
\hline DM1 & $\%$ & $\%$ & $\%$ & $\%$ \\
DM2 & 40 & 33 & 15 & 16 \\
DM3 & 32 & 87 & 24 & 33 \\
DM4 & 38 & 80 & 21 & 39 \\
DM5 & 53 & 91 & 56 & 46 \\
DM6 & 68 & 89 & 45 & 66 \\
DM7 & 64 & 24 & - & - \\
DM8 & 47 & 75 & - & - \\
DM9 & 61 & 33 & - & - \\
cDM1 & 41 & 58 & - & - \\
cDM2 & 53 & 70 & 34 & 73 \\
MC1 & 55 & 48 & 46 & 57 \\
MC2 & 114 & 119 & 111 & 54 \\
MC3 & 101 & 74 & 112 & 131 \\
MC4 & - & - & 84 & \\
\hline & - & - & 113 & \\
\hline
\end{tabular}



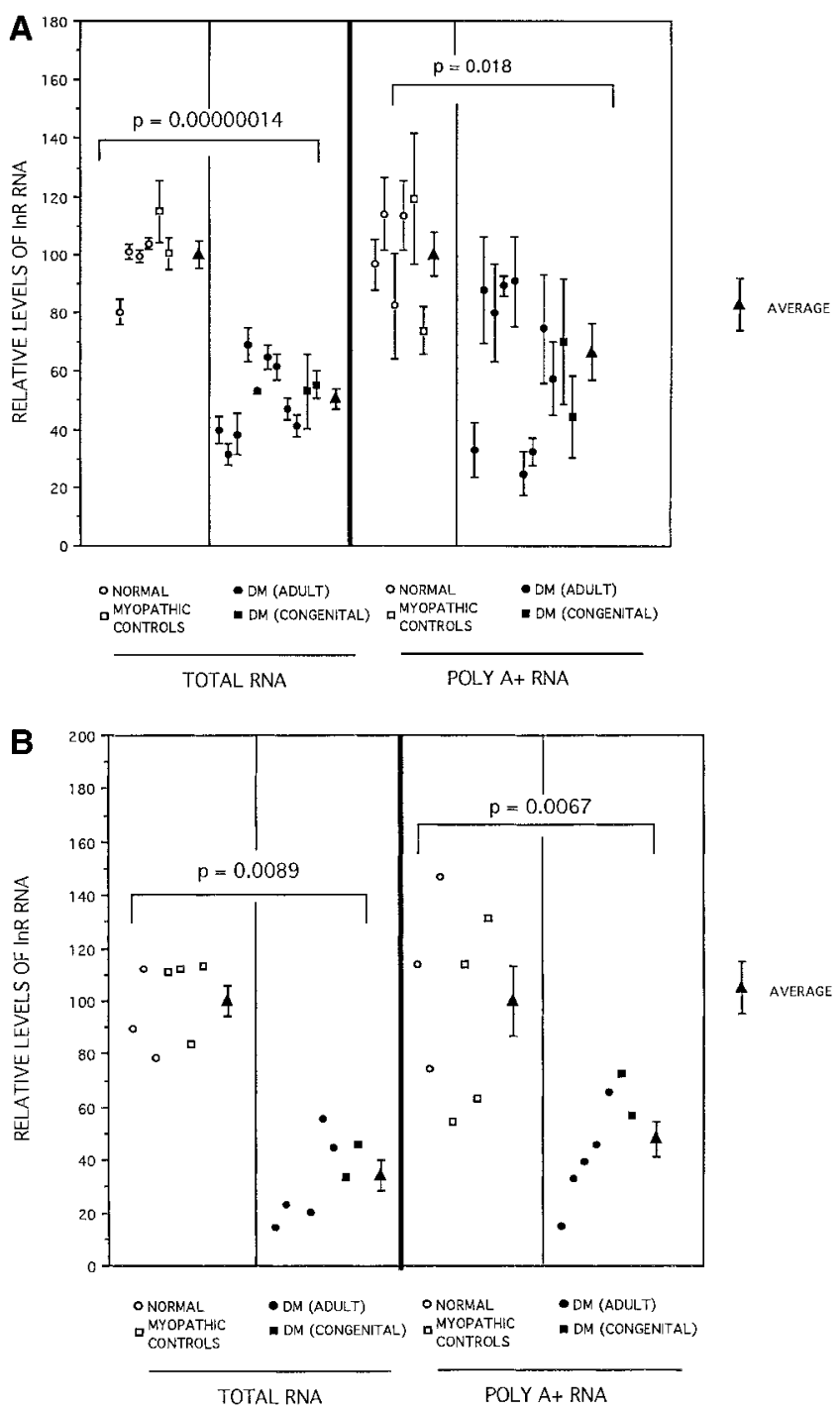

Figure 2. Insulin receptor RNA shows statistically significant decreases in myotonic dystrophy patient muscle biopsies. Shown are the summarized results of QMF-PCR of muscle biopsies from adult onset myotonic dystrophy patients, congenital myotonic dystrophy patients, normal controls, and myopathic controls. Data are shown for insulin receptor RNA quantitated as a ratio of dystrophin RNA $(A)$, and sodium channel RNA $(B)$. The graphs were normalized so that the ratio of insulin receptor vs. control RNA was equal to 100 . The data show that myotonic dystrophy muscle (both adult onset and congenital) shows significantly reduced amounts of insulin receptor RNA in both total and polyA+ pools, relative to both dystrophin and sodium channel RNAs.

phin mRNA levels as the cause of our results, we conducted similar QMF-PCR experiments using the adult skeletal muscle sodium channel RNA as an alternative internal control. Each sample was analyzed using 1-2 independent PCR reactions, and ratios were determined using automated sequencer traces (Fig. 2 B). The insulin receptor/ $\mathrm{Na}^{+}$channel ratios in myotonic dystrophy patients showed statistically significant decreases in total RNA pools to $\sim 33 \%$ of levels seen in the normal and myopathic controls $(P=0.0089)$. This decrease was also present in polyA + RNA pools $(\sim 49 \%$ of normal and myo- pathic controls) $(P=0.0067)$. Thus, insulin receptor RNA showed decreased accumulation in myotonic dystrophy patient biopsies. These changes were disease-specific, obtained with two different unrelated internal controls, and were highly statistically significant.

Protein studies. Five of the adult onset myotonic dystrophy biopsies and four myopathic controls were selected for quantitative immunoblotting and immunofluorescence studies. Immunoblots were developed for insulin receptor proteins using a polyclonal antibody, and the signals compared to normal and myopathic controls (Fig. $3 A$ ). The posttransfer gel corresponding to the insulin receptor immunoblot was stained for residual myosin heavy chain as previously described (31) as a control for muscle tissue loading (Fig. $3 \mathrm{~B}$ ). All myotonic dystrophy biopsies showed a decrease in insulin receptor protein relative to adjacent controls, and this was not a consequence of differences in protein loaded on the gel (Fig. 3, $A$ and $B$ ).

It is well documented that some myotonic dystrophy patients show selective loss of slow-twitch (type 1) myofibers, leading to fiber type II predominance (1). Some studies have shown decreased insulin binding to rodent fast-twitch fibers relative to slow-twitch fibers, however, in higher vertebrates such correlations have not been confirmed (35). We were nevertheless concerned that the decrease in insulin receptor levels in myotonic dystrophy could be a consequence of preferential loss of type I fibers. To test this concern, we studied five myotonic dystrophy biopsies for fiber type content, both by immunoblotting (Fig. 3, $C$ and $D$ ), and by immunofluorescence (data not shown). Patient $\mathrm{DM}_{2}$ showed dramatic loss of type I fibers, while the other patients had less extensive fiber type predominance. Insulin receptor levels were decreased in each sample irrespective of the extent of fiber type predominance (Fig. 3). Immunofluorescence staining of cryosections also showed a decrease of signal intensity in myotonic dystrophy patients relative to controls, although the signal was very weak (data not shown).

The insulin receptor immunoblot was quantitated by computer densitometry, and the levels of insulin receptor protein were normalized to total myosin content and expressed as a percentage of the average levels seen in controls (Fig. 3 E). Myotonic dystrophy patients showed an $\sim 30 \%$ decrease in protein levels $(P=0.054)$.

\section{Discussion}

The molecular pathogenesis of myotonic dystrophy is controversial. It is clear that the disease process is initiated by the pathological expansion of a trinucleotide GTG repeat in the $3^{\prime}$ untranslated region of a protein kinase gene (DM kinase). The mechanisms by which the expanded repeat causes the highly variable and multisystemic clinical features enigmatic of myotonic dystrophy, however, are not yet clear. There are currently three pathogenetic hypotheses with data that support each: (a) loss of function/haploinsufficiency; (b) chromatin changes with multigene transcription changes, (c) generalized RNA metabolism defect mediated by the mutant RNA.

The loss of function hypothesis suggests that the expanded repeat leads to a loss of transcription, translation, or both. Each patient, however, is heterozygous, so this change should only affect transcription or translation from the mutant allele (haploinsufficiency). Consistent with this model, early publications showed that RNA levels of the DM kinase were reduced in both patient muscle and in cell cultures $(12,13,14,15)$. The 


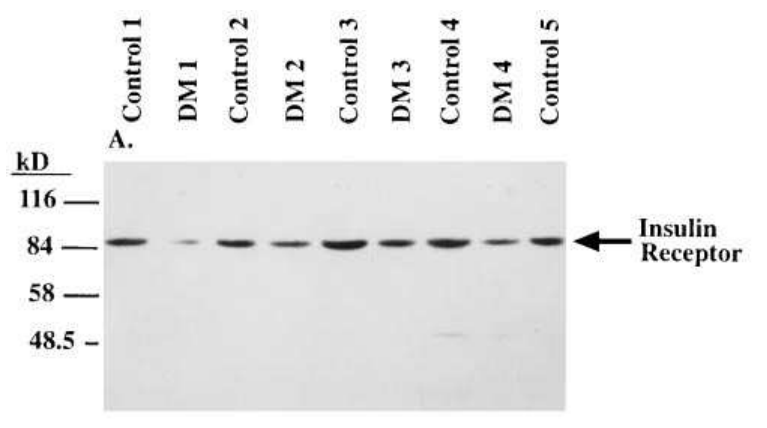

B.

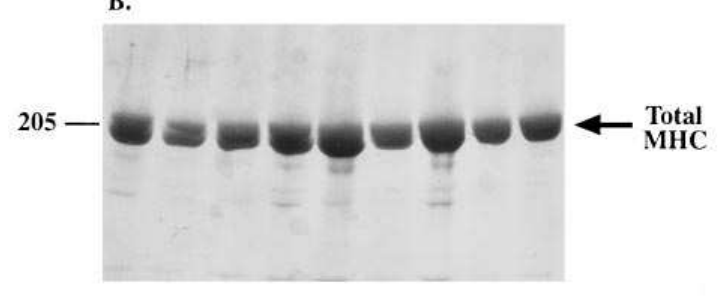

C.

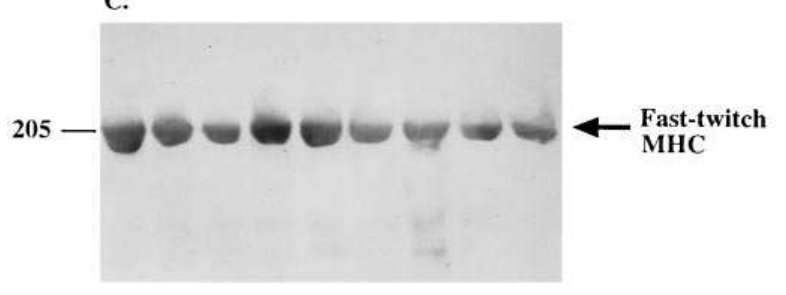

D.

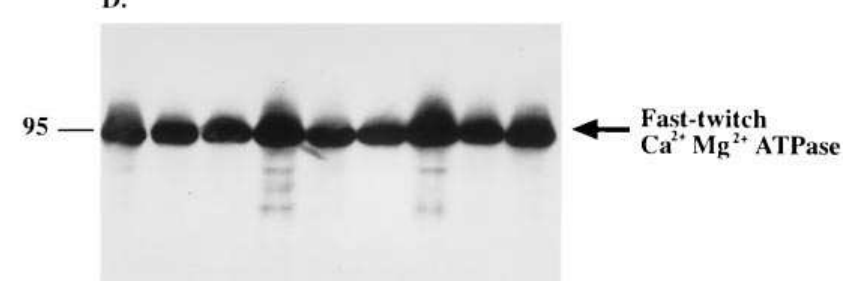

$\mathrm{E}$

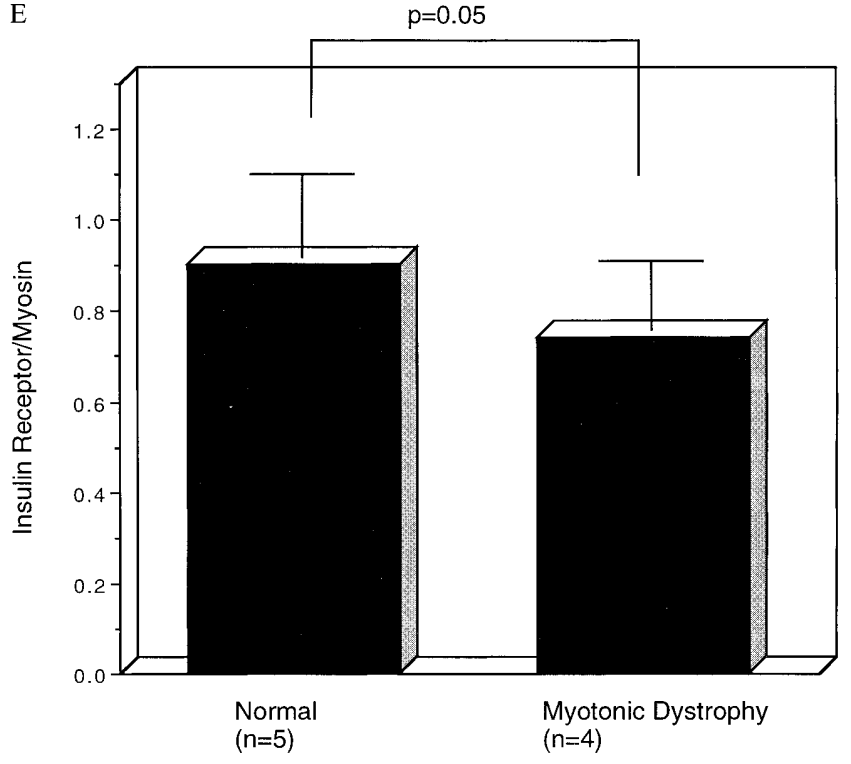

Figure 3. Immunoblot analysis shows decreased insulin receptor protein in muscle biopsies from myotonic dystrophy patients. Shown is immunoblot analysis of the insulin receptor $(A)$, and corresponding posttransfer Coomassie blue staining of the myosin heavy chain $(B)$. corresponding protein also showed deficiency in patient cells (36). More recent studies have documented transcriptional activity from the mutant DM kinase gene resulting in accumulation of mutant RNA in total RNA pools, although the abnormal RNA is not polyadenylated and is not available for translation $(16,17,18)$. While all these data are consistent with haploinsufficiency of the cAMP kinase, it is difficult to understand how such mild changes in protein levels could result in the dramatic clinical variability seen in myotonic dystrophy patients. Moreover, transgenic mice that have no functional DM kinase (homozygous recessive, complete loss of function) show only a mild, late onset muscle phenotype, and share few of the other symptoms of the human disease $(37,38)$.

The second hypothesis for disease pathogenesis is that the presence of the expanded repeat in chromatin leads to altered chromatin structure (39) and abnormal nucleosomes binding $(40,41)$. The altered chromatin structure could result in longrange effects on gene transcription, perhaps altering expression of both the DM kinase gene and other neighboring genes. If gene transcription were in fact decreased from a series of neighboring genes, then a contiguous gene haploinsufficiency syndrome could result, as is seen in contiguous gene deletion syndromes. The clinical variability of the disease could be explained by a relationship between the size of the CTG expansion mutation and the number of neighboring genes affected. If this mechanism is true, then it might be expected that DM kinase transcription from the mutant allele is turned off; however, this is clearly not the case $(16,17,18)$. A series of novel genes have been identified neighboring the DM kinase gene $(42,43,44)$, however, it is not yet clear if transcription from any of these genes is affected by expansion of the DM kinase CTG repeat. It is important to note that the insulin receptor gene is in fact on chromosome 19, as is the DM kinase genelong range transcriptional inactivation of chromosome 19 could conceivably explain the decrease in insulin receptor RNA we describe here.

The third hypothesis suggests that the presence of the CTG expansion in RNA could have a deleterious effect on the cell, altering RNA metabolism of a number of genes. This dominant negative RNA hypothesis is supported by four publications from three laboratories using different experimental systems, and by data presented in this paper. In situ nucleic acid hybridization experiments done by Singer's group (45) found that relatively large amounts of RNA containing the expansion mutation could be found in nuclei of muscle and cultured fibroblasts from myotonic dystrophy patients. This RNA was not polyadenylated, appeared as aggregates in the nucleus, and was not physically associated with the mutant copy of the gene (DNA). In parallel, both we (16) and Krahe et al. (46) showed that the DM kinase RNA containing the expansion mu-

Identical immunoblots were also incubated with monoclonal antibodies directed against fast-twitch isoforms of myosin heavy chain $(C)$, and $\mathrm{Ca}^{2+} \mathrm{Mg}^{2+}$ ATPase $(D)$ to investigate the extent of fiber type II (fast-twitch) predominance. All muscle biopsies from myotonic dystrophy patients show a reduction in levels of insulin receptor protein $(A)$. These reductions are not explained by reduced protein content of the lanes $(B)$, or fiber-type predominance $(C$ and $D)$. (E) Quantitation of immunoblots, which documents the decrease in insulin receptor protein. 
tation was present at high levels in patient muscle, but that the mutant transcripts were poorly polyadenylated, and were presumably not available for translation. In addition, we found that the normal RNA transcripts from the normal copy of the gene were similarly poorly polyadenylated, suggesting a trans effect of the mutant RNA on RNA metabolism (16). More recently, Timchenko and co-workers conducted an elegant series of biochemical and molecular studies identifying and characterizing RNA binding proteins that specifically recognize the CUG repeat present in DM kinase transcripts, showing that these proteins are cytoplasmic in normal cells, but are sequestered in the nuclei of DM patient cells $(47,48)$.

If the dominant negative RNA mechanism is valid, then it should be possible to identify other RNAs whose metabolism is altered in myotonic dystrophy patient tissues. The most obvious candidates for such RNAs affected in trans are those corresponding to biochemical abnormalities that have previously been documented in myotonic dystrophy patient muscle. It has been well documented that myotonic dystrophy patients have increased insulin resistance, and that this endocrine abnormality is possibly the consequence of decreased numbers of insulin receptors in muscle. We therefore tested the hypothesis that the RNA and protein corresponding to the insulin receptor gene is decreased in patient muscle. If true, then this data would lend support to the dominant negative RNA hypothesis.

We quantitated insulin receptor RNA and protein levels in muscle biopsies from a series of adult onset myotonic dystrophy patients, neonatal onset congenital myotonic dystrophy patients, myopathic disease controls, and normal controls. Insulin receptor RNA levels were measured in both total and polyA + RNA pools, and quantitations were done relative to both dystrophin RNA and sodium channel RNA using an assay we have previously described (QMF-PCR). We found statistically significant reductions in insulin receptor RNA in myotonic dystrophy muscle. The reductions were disease-specific, and were statistically significant in both total and polyA+ pools. Similar reductions were present when normalizing to either dystrophin or the sodium channel RNAs. Consistent with the RNA data, we found a disease-specific decrease in insulin receptor protein in DM patient muscle.

These data taken together show that the mutant DM kinase gene is transcribed into RNA containing the expansion mutation, and that the mutant RNA is improperly processed, and forms aggregates within the patient nuclei where it sequesters CUG RNA binding proteins, making them unavailable for their normal cytosolic functions. Loss of CUG binding proteins from the cytoplasm then has a dominant effect on RNA metabolism, leading to disregulation of multiple RNAs, including the insulin receptor RNA. This hypothesis could explain the dominant inheritance, dramatic clinical variability, and multisystemic nature of the disease through alterations of specific RNA molecules of other genes, in a developmentaland tissue-specific manner.

\section{Acknowledgments}

The authors thank Hisashi Kobayashi, M.D., Ph.D., and Selma Witchel, M.D. for helpful advice and comments, Elisabetta Menegazzo, M.D., for providing clinical data on some of the patients studied, Guillermo Romero, Ph.D. for monoclonal antibodies against the insulin receptor, and Massimo Gennarelli for DNA studies.
Support was provided in part by a grant from the National Institutes of Health (NS34193). E.P. Hoffman is an Established Investigator of the American Heart Association.

\section{References}

1. Harper, P.S. 1989. Myotonic Dystrophy. 2nd ed. W.B. Saunders Company, Philadelphia. $331 \mathrm{pp}$.

2. Harper, P.S., and R. Rudel. 1994. Myotonic Dystrophy. In Myology. 2nd ed. A.G. Engel, and C. Franzini-Armstrong, editors. McGraw-Hill Inc., New York. 1192-1219.

3. Brook, J.D., M.E. Currach, H.G. Harley, A.J. Buckler, D. Church, H. Aburatani, K. Hunter, V.P. Stanton, J. Thirion, T. Hudson, et al. 1992. Molecular basis of myotonic dystrophy: expansion of a trinucleotide CTG repeat at the $3^{\prime}$ end of the transcript encoded a protein kinase family member. Cell. 68:799-808.

4. Buxton, J., P. Shelbourne, J. Davies, C. Jones, T.V. Tongeren, C. Aslanidis, P.D. John, G. Jansen, M. Anvret, B. Riley, R. Williamson, and K. Johnson. 1992. Detection of an unstable fragment of DNA specific to individuals with myotonic dystrophy. Nature (Lond.). 355:547-548.

5. Fu, Y.H., A. Pizzuti, R.G. Fenwick, J. King, S. Rajnarayan, P.W. Dunne, J. Dubel, G.A. Nasser, T. Ashizawa, P. Jong, et al. 1992. An unstable triplet repeat in the gene related to myotonic muscular dystrophy. Science (Wash. DC). 255:1256-1258.

6. Mahadevan, M., C. Tsilfidis, L. Sabourin, G. Shutler, C. Amemiya, G. Jansen, C. Neville, M. Narang, J. Barcelo, K. O'Hoy, S. Leblong, J. Earle-Macdonald, P.J. John, B. Wieringa, and R.G. Korneluk. 1992. Myotonic dystrophy mutation: an unstable CTG repeat in the $3^{\prime}$ untranslated region of the gene. Science (Wash. DC). 255:1253-1255.

7. Shutler, G., R.G. Korneluk, C. Tsilfidis, M. Mahadevan, J. Bailly, H. Smeets, G. Jansen, B. Wieringa, F. Lohman, C. Aslanidis, and P.D. John. 1992. Physical mapping and cloning of the proximal segment of the myotonic dystrophy gene region. Genomics. 13:518-525.

8. Pieretti, M., F. Zhang, Y.H. Fu, S.T. Warren, B.A. Oostra, C.F. Caskey, and D.L. Nelson. 1991. Absence of expression of the FMTR-1 gene in Fragile X syndrome. Cell. 66:817-822.

9. Campuzano, V., L. Montermini, M.D. Molto, L. Pianese, M. Cossee, F. Cavalcanti, E. Monros, F. Rodius, F. Duclos, A. Monticelli, et al. 1996. Friedreich's ataxia: autosomal recessive disease caused by an intronic GAA triplet repeat expansion. Science (Wash. DC). 271:1423-1427.

10. Hoffman, E.P. 1992. Myotonic dystrophy: a stutter, stumble, or fall of a kinase? Curr. Biol. 6:309-311.

11. Sabouri, L.A., M.S. Mahadevan, M. Narang, D.S. Lee, L.C. Surh, and R.G. Korneluk. 1993. Effect of the myotonic dystrophy (DM) mutation on mRNA levels of the DM gene. Nat. Genet. 4:233-238.

12. Carango, P., J.E. Noble, H.G. Marks, and V.L. Funanage. 1993. Absence of myotonic dystrophy protein kinase (DMPK) mRNA as a result of a triplet repeat expansion in myotonic dystrophy. Genomics. 18:340-348.

13. Fu, Y.H., D.L. Friedman, S. Richards, J.A. Pearlman, R.A. Gibbs, A. Pizzuti, T. Ashizawa, M.B. Perryman, G. Scarlato, R.G. Fenwick, and C.T. Caskey. 1993. Decreased expression of myotonic protein kinase messenger RNA and protein in the adult form of myotonic dystrophy. Science (Wash. DC). 260: 235-238.

14. Hofmann-Radvanyi, H., C. Lavedan, S.P. Rabes, D. Savoy, C. Duros, K. Johnson, and C. Junien. 1993. Myotonic dystrophy: absence of CTG enlarged transcript in congenital forms, and low expression of the normal allele. Hum. Mol. Genet. 2:1263-1266.

15. Novelli, G., M. Gennarelli, G. Zelano, A. Pizzuti, C. Fattorini, C.T. Caskey, and B. Dallapiccola. 1993. Failure in detecting mRNA transcripts from the mutated allele in myotonic dystrophy muscle. Biochem. Mol. Biol. Int. 29:291-297.

16. Wang, J., E. Pegoraro, E. Menegazzo, M. Gennarelli, R.C. Hoop, C. Angelini, and E.P. Hoffman. 1995. Myotonic dystrophy: evidence for a dominant-negative RNA mutation. Hum. Mol. Genet. 4:599-606.

17. Hudson, A.J., M.W. Huff, C.G. Wright, M.M. Silver, T.C.Y. Lo, and D. Banerjee. 1987. The role of insulin resistance in the pathogenesis of myotonic muscular dystrophy. Brain. 110:469-488.

18. Moxley, R.T., W.J. Kingston, R.C. Griggs, and J.N. Livingston. 1987. Lack of rapid enhancement of insulin action after oral glucose challenge in myotonic dystrophy. Diabetes. 36:693-701.

19. Perurena, O.H., and B.W. Festoff. 1989. Environmental influence on altered receptor function in a genetic disease: insulin and glucose affect insulin receptors in myotonic dystrophy. J. Neurol. Sci. 89:15-25.

20. Krentz, A.J., N.H. Coles, A.C. Williams, and M. Nattrass. 1990. Abnormal regulation of intermediary metabolism after oral glucose ingestion in myotonic dystrophy. Metab. Clin. Exp. 39:938-942.

21. Piccardo, M.G, G. Pacini, M. Rose, and R. Vichi. 1991. Insulin resistance in myotonic dystrophy. Enzyme (Basel). 45:14-22.

22. Fratino, P., R. Bellomo, R. Bellazzi, E. Martignoni, and G. Nappi. 1982. Insulin receptors in myotonic dystrophy. Acta Neurol. Belg. 82:128-137.

23. Harley, H.G., J.D. Brook, S.A. Rundle, S. Crow, W. Reardon, A.J. Buckler, P.S. Harper, D.E. Housman, and D.J. Shaw. 1992. Expansion of an instable DNA region and phenotypic variation in myotonic dystrophy. Nature 
(Lond.). 355:545-546.

24. Wang, J., C.V. Rojas, J. Zhou, L.S. Shwartz, H. Nicholas, and E.P. Hoffman. 1992. Sequence and genomic structure of the human adult skeletal muscle sodium channel alpha subunit gene on 17q. Biochem. Biophys. Res. Commun. 182:794-801.

25. Ebina, Y., L. Ellis, K. Jarnagin, M. Edery, L. Graf, E. Clauser, J. Ou, F. Masiarz, Y.W. Kan, I.D. Goldfine, R.A. Roth, and W.J. Rutter. 1985. The human insulin receptor cDNA: the structural basis for hormone-activated transmembrane signalling. Cell. 40:747-758.

26. Koenig, M., E.P. Hoffman, C.J. Bertelson, A.P. Monaco, C. Feener, and L.M. Kunkel. 1987. Complete cloning of the Duchenne muscular dystrophy (DMD) cDNA and preliminary genomic organization of the DMD gene in normal and affected individuals. Cell. 50:509-517.

27. Perryman, M.D., S.A. Kerner, T.J. Bohlmeyer, and R. Roberts. 1986. Isolation and sequence analysis of a full-length cDNA form human $\mathrm{M}$ creatine kinase. Biochem. Biophys. Res. Comm. 140:981-989.

28. McClelland A., L.C. Kuehn, and F.H. Ruddle. 1984. The human transferrin receptor gene: genomic organization, and the complete primary structure of the receptor deduced from a cDNA sequence. Cell. 39:267-274.

29. Schwartz, L.S., J. Tarleton, B. Popovich, W. Seltzer, and E.P. Hoffman. 1992. Fluorescent multiplex linkage analysis and carrier detection for Duchenne/Becker muscular dystrophy. Am. J. Hum. Genet. 51:721-729.

30. Zhou, J.H., and E.P. Hoffman. 1994. Pathophysiology of sodium channelopathies: Studies of sodium channel expression by quantitative multiplex fluorescence polymerase chain reaction. J. Biol. Chem. 269:18563-18571.

31. Hoffman, E.P., K.H. Fischbeck, R.H. Brown, M. Johnson, R. Medori, J.D. Loike, J.B. Harris, R. Waterston, M. Brooke, L. Specht, et al. 1988. Dystrophin characterization in muscle biopsies from Duchenne and Becker muscular dystrophy patients. New Eng. J. Med. 318:1363-1368.

32. Miller, J.B., M.T. Crow, and F.E. Stockdale. 1985. Slow and fast myosin heavy chain content defines three types of myotubes in early muscle cell cultures. J. Cell Biol. 101:1643-1650.

33. Kaprielian, Z., and D.M. Fambrough. 1987. Expression of fast and slow isoforms of the $\mathrm{Ca}^{2+}$-ATPase in developing chick skeletal muscle. Dev. Biol. 124:490-503

34. Shome, K., X.Q. Xu, and G. Romero. 1995. Brefeldin A inhibits insulindependent receptor redistribution in HIRcB cells. FEBS Lett. 357:109-114.

35. Boge, A., H. Sauerwein, and H.H. Meyer. 1995. IGF-I and insulin receptors in bovine skeletal muscle: comparisons of different developmental ages, two different genotypes, and various individual muscles. Exp. Clin. Endocrinol. Diabetes. 103:99-104.

36. Koga, R., Y. Nakao, Y. Kurano, T. Tsukahara, A. Nukamura, S. Ishiura, I. Nonaka, and K. Arahata. 1994. Decreased myotonin-protein kinase in the skeletal and cardiac muscles in myotonic dystrophy. Biochem. Biophys. Res. Commun. 202:577-585.
37. Reddy, S., D.B. Smith, M.M. Rich, J.M. Leferovich, P. Reilly, B.M. Davis, K. Tran, H. Rayburn, R. Bronson, D. Cros, R.J. Balice-Gordon, and D. Housman. 1996. Mice lacking the myotonic dystrophy protein kinase develop a late onset progressive myopathy. Nat. Genet. 13:325-335.

38. Jansen, G., P.J. Groenen, D. Bachner, P.H. Jap, M. Coerwinkel, F. Oerlemans, W. van den Broek, B. Gohlsch, D. Pette, J.J. Plomp, et al. 1996. Abnormal myotonic dystrophy protein kinase levels produce only mild myopathy in mice. Nat. Genet. 13:316-324.

39. Otten, A.D., and S.J. Tapscott. 1995. Triplet expansion in myotonic dystrophy alters the adjacent chromatin structure. Proc. Natl. Acad. Sci. USA. 92: 5465-5469.

40. Wang, Y.H., A. Sorour, S. Kang, R.D. Wells, and J.D. Griffith. 1994 Preferential nucleosome assembly at DNA triplet repeats from the myotonic dystrophy gene. Science (Wash. DC). 265:669-671.

41. Wang, Y.H., and J.D. Griffith. 1994. Expanded CTG triplet blocks from the myotonic dystrophy gene create the strongest known natural nucleosome positioning elements. Genomics. 25:570-573.

42. Jansen, G., D. Bachner, M. Coerwinkel, N. Wormskamp, H. Hameister, and B. Wieringa. 1995. Structural organization and developmental expression pattern of the mouse WD-repeat gene DMR-N9 immediately upstream of the myotonic dystrophy locus. Hum. Mol. Genet. 4:843-852.

43. Mahadevan, M.S., S. Baird, J.E. Bailly, G.G. Shutler, L.A. Sabourin, C. Tsilfidis, C.E. Neville, M. Narang, and R.G. Korneluk. 1995. Isolation of a novel G protein-coupled receptor (GPR4) localized to chromosome 19q13.3. Genomics. 30:84-88.

44. Boucher, C.A., S.K. King, N. Carey, R. Krahe, C.L. Winchester, S. Rahman, T. Creavin, P. Meghji, M.E. Bailey, F.L. Chartier, et al. 1995. A novel homeodomain-encoding gene is associated with a large $\mathrm{CpG}$ island interrupted by the myotonic dystrophy unstable (CTG)n repeat. Hum. Mol. Genet. 4:19191925.

45. Taneja, L.K., M. McCurrach, M. Schalling, D. Housman, and R.H Singer. 1995. Foci of trinucleotide repeat transcripts in nuclei of myotonic dystrophy cells and tissues. J. Cell Biol. 128:996-1002.

46. Krahe, R., T. Ashizawa, C. Abbruzzese, E. Roeder, P. Carango, M. Giacanelli, V.L. Funanage, and M.J. Siciliano. 1995. Effect of myotonic dystrophy trinucleotide repeat expansion on DMPK transcription and processing. Genomics. 28:1-14.

47. Timchenko, L.T., N.A. Timchenko, C.T. Caskey, and R. Roberts. 1996. Novel proteins with binding specificity for DNA CTG repeats and RNA CUG repeats: implications for myotonic dystrophy. Hum. Mol. Genet. 5:115-121.

48. Timchenko, L.T., J.W. Miller, N.A. Timchenko, D.R. DeVore, K.V. Datar, L. Lin, R. Roberts, C.T. Caskey, and M.S. Swanson. Identification of a (CUG)n triplet repeat RNA-binding protein and its expression in myotonic dystrophy. Nucl. Acids Res. In press. 